\title{
Forskningscirkeln som resurs för utveckling av bibliotekari- ers läsfrämjande verksamhet
}

\begin{abstract}
In recent decades, changes in the professional role of librarians - in terms of both content and complexity - have led to an increased need for further education. This need is particularly prominent in reading promotion for groups where reading and reading proficiency is decreasing (Sverige. Litteraturutredningen 2010). This article concerns two "research circles" where librarians reflected on and explored different possibilities for reading promotion. The purpose of this article is to understand how the research circle was used as a resource for knowledge building, and for the changes and development of the librarians' work with reading promotion in different contexts. The overarching theoretical framework is sociocultural (Vygotskij 1978, Bakhtin, 1984; Wertsch 1998). The source of data used includes audio-recorded meetings, the reflections I wrote in proximity to the meetings and interviews with the participants. The results show how the participants became important resources for each other through the exchange of experiences and through critical reflection. The investigations challenged the participants' flexibility and ability to cope with uncertainty and to remain open to change. The interviews indicate that there have been changes in the participants' understanding of reading-promotion and that this kind of supplementary education has the prerequisites to achieve lasting results. The research circle work was linked to a discussion regarding the changed professional role of librarians and the challenge of linking the profession to a wider social and democracy perspective, where questions about access to language, knowledge, power and democratic influence are crucial for the development of librarians' professional work.
\end{abstract}

Keywords: aktionsforskning, bibliotekariers arbete, kompetensutveckling, kollaboration, kritisk reflektion, läsfrämjande.

\section{Inledning}

I Sverige såväl som i andra delar av världen har bibliotekens roll och funktion genomgått stora förändringar under de senaste decennierna (Frenander \& Lindberg, 2012; Hansson, 2015). Förändringarna har sin grund i den snabba utvecklingen av kommunikations- och informationsteknologin, globaliseringen och den politiska och ekonomiska utvecklingen. Det senare har lett till att folkbibliotekens verksamhet successivt blivit mer marknadsorienterad och därmed föremål för kontrollmekanismer hämtade från den privata sektorn (Audunson, 2005; Hansson, 2015; Kann-Christensen \& Andersen, 2009; Michnik, 2014;). Antalet bibliotek, aktiva låntagare och utlån har minskat 
medan användningen av e-medier och andra aktiviteter på biblioteken ökat (Höglund, 2012; Ranemo, 2017). Biblioteken tillhandahåller fri tillgång till information, böcker, musik, video, databaser och e-böcker samt lokaler för studier och informationssökning där bibliotekariernas roll blir att bistå, vägleda och utbilda. Verksamheten omfattar också aktiviteter som t.ex. bokprat, författarbesök, utställningar och olika former av samarbeten med förskolor och skolor. Genom alla dessa funktioner och aktiviteter ska det allmänna biblioteksväsendet, enligt $N y$ Bibliotekslag (2012), fullfölja sitt uppdrag att "verka för det demokratiska samhällets utveckling".

Bibliotekens utveckling har inneburit förändringar i bibliotekariernas yrkesroll med avseende på både innehåll och komplexitet, inte minst genom att bibliotekariernas pedagogiska funktion blivit alltmer framträdande. Eftersom de flesta bibliotekarier saknar pedagogisk utbildning (Kungliga biblioteket, 2015) är behovet av kompetensutveckling omfattande, särskilt avseende folkbibliotekens läsfrämjande verksamhet som i $\mathrm{Ny}$ Bibliotekslag (2012) har starkare fokus än tidigare. Flera insatser för kompetensutveckling av bibliotekarier har kommit till i kölvattnet av Litteraturutredningen Läsandets kultur. Slutbetänkande (Sverige Litteraturutredningen, 2012) och det handlingsprogram för läsfrämjande verksamhet utanför skolan som på uppdrag av regeringen tagits fram av Kulturrådet (Statens kulturråd, 2014).

I ett samarbete mellan Region Skåne och Malmö högskola erbjöds under läsåret 2015/2016 en forskningsbaserad kompetensutveckling för bibliotekarier i syfte att stärka folkbibliotekens läsfrämjande verksamhet. Kompetensutvecklingen kom att genomföras i form av forskningscirklar (Lindholm 2008; Persson 2009) där yrkesverksamma och forskare tillsammans formulerar frågor och utvecklingsområden som sedan utforskas i deltagarnas praktiska yrkesutövning. Finansiering för två forskningscirklar gav möjlighet för 14 bibliotekarier och en bibliotekschef att tillsammans med mig som handledare diskutera vad läsfrämjande är och hur läsfrämjande arbete kan bedrivas mot olika grupper kopplat till demokrati- och tillgänglighetsfrågor. Deltagarna tog del av varandras kunskaper och erfarenheter, diskuterade forskningsresultat och genomförde individuella utforskande projekt i den egna verksamheten. 10 småskaliga forskningsliknande projekten ${ }^{\mathrm{i}}$ publicerades $\mathrm{i}$ rapporten Aktionsforskande bibliotekarier. En rapport om läsfrämjande verksamhet (Bergman m.fl. 2016a). Dokumenterade träffar och projekt samt intervjuer som genomfördes med deltagare gav mig möjlighet att undersöka vad som skedde i processen.

Syftet är att förstå hur det kollaborativa arbetet i en forskningscirkel kan användas som resurs för kunskapsbildning och utveckling av bibliotekariers läsfrämjande verksamhet. Studien är influerad av aktionsforskning genom intresset för förändring och utveckling av en verksamhet och för den process som skapar förutsättningar för förändring (Aagaard Nilesen \& Svensson, 2006; Somekh, 2006).

\section{Teoretiska perspektiv och centrala begrepp}

Studien har ett övergripande sociokulturellt perspektiv där interaktion ses som en fundamental förutsättning för lärande (Vygotskij, 1978). Inom sociokulturell teoribildning riktas uppmärksamheten bland annat mot hur individer och grupper använder kulturella redskap, fysiska och intellektuella, som resurser och hur samspelet mellan resurs och individ ser ut (Wertsch, 1991). Lärandet och de kulturella redskap vi använder är kulturellt, socialt och historiskt bestämda och kan möjliggöra eller begränsa våra handlingar (Wertsch, 1991). Det viktigaste kulturella redskapet för deltagande i sociala praktiker och för tänkande och lärande är språket (Vygotskij, 1978; Wertsch, 1991).

För att förstå interaktionen i forskningscirkeln har jag använt mig av begreppen intersubjektivitet (Rommetveit, 1974) och alteritet (Wertsch, 1998), vilka båda är framträdande i all mänsklig kommunikation. Begreppen står för två krafter, dynamiskt integrerade men svåra att balansera. Intersubjektiviteten är viktig för gemenskapen och handlar om samförståndet och känslan av att dela en social verklighet. Alteriteten är förbunden med språkets dialogiska funktion, grundläggande för allt meningsskapande, och representerar de olika perspektiv och potentiella konflikter som alltid uppstår i spänningen mellan olika röster (Bakhtin, 1984). Flerstämmigheten (Bakhtin, 1984), där skilda perspektiv och uppfattningar får utrymme, ses som något positivt och kan användas som tankeredskap (Lotman, 1990) för att utveckla ny kunskap och förståelse. I dessa teorier och begrepp finns 
flera paralleller till forskning om kritisk reflektion och dess betydelse för förändring och utveckling i professionell verksamhet (Svensson 2007; Fricke 2013).

När det gäller den kritiska reflektionens betydelse hämtar jag inspiration och begrepp från Mezirows teori om transformativt lärande (Mezirow \& Associates 2000; Mezirow 1991). Genom den kritiska aktiviteten kan vi bli medvetna om och ifrågasätta de antaganden som styr vårt tänkande, våra känslor och vårt handlande och därigenom göra dem mer öppna för förändring. Mezirow (1991) skiljer mellan tre olika former av reflektion; reflektion över innehåll (content), processer (processes) och antaganden/förgivettaganden (premises). Reflektion över innehåll innebär att vi reflekterar över vad vi vet t.ex. när vi beskriver ett problem, medan reflektioner över processer avser hur vi går till väga, t.ex. de metoder vi använder för att lösa problem. När objektet för reflektionen är ett antagande eller förgivettagande nås en annan nivå av abstraktion. En sådan nivå av reflektion innebär ett ifrågasättande av de antaganden som vårt vetande bygger på och har därmed en potential att förändra en etablerad referensram, reflektionen blir kritisk (Mezirow, 1991, s. 186). Den kritiska reflektionen kan riktas mot såväl våra egna, självreflektion, som andras antaganden och sätt att tänka och handla. I den kritiska självreflektionen finns potentialer för transformativ lärande: "Significant personal and social transformation may result from this kind of reflektion" (Mezirow, 1991, s. 186).

Den kritiska reflektionens sätts ofta igång av något som skapar missnöje eller som provocerar, $a$ disorienting dilemma, vilket enligt Mezirow (1998) skapar förutsättningar för en omformulering av en tidigare förståelse av ett fenomen eller en upplevelse. Den kritiska reflektionen ses som en nödvändig men inte tillräcklig förutsättning för förändring ( se t.ex. Taylor 2007, Mälkki \& Lindblom-Ylänne 2012). Mälkki (2011) menar att Mezirows syn på reflektion som en i huvudsak rationell och kognitiv process behöver kompletteras med sociala och emotionella dimensioner. Det kan t.ex. finnas sociala och känslomässiga orsaker till kritiska och självkritiska aktiviteter. Sådana orsaker kan också utgöra hinder för kritisk reflektion och manifestera sig som motstånd mot att ifrågasätta sitt eget och den egna gruppens sätt att tänka, känna och handla. Motstånd behövs, enligt Mälkki (2011, s. 35), för att vi ska behålla en koherent världsbild och känslor av trygghet och acceptans i en grupp men kan också ge upphov till ambivalenser. Den oenighet och frustration som kan uppstå när vi tillsammans brottas med svårigheter ses som betydelsefull för att få syn på de tysta förutsättningar som styr våra handlingar (Lycke \& Handal 2012) och för att nå djupare insikter (Somekh, 2006). Därmed kan svårigheterna bli till drivkrafter för förändring (Engeström \& Sannino 2009:4, 7).

Jag använder begreppet kollaboration (Bruce, Flynn \& Stagg-Peterson, 2011; Capobianco, 2007; Somekh, 2006) för det samarbete, på så jämlik bas som möjligt, som jag och deltagarna eftersträvat. Begreppet har i sin engelska ursprungsbetydelse, 'co-labouring', en stark koppling till ömsesidighet och till deltagarnas engagemang för att över tid bygga upp en delad repertoar av berättelser, begrepp och sätt att tänka och för att tillsammans lösa gemensamma problem (Somekh, 2006). I den demokratiska dialogen där utrymme ges för allas röster finns förutsättningar för den kollaborativa kritiska reflektionen, som ses som kärnan i aktionsforskning (Fricke, 2013). Kritiska reflektioner kollegor emellan, där invanda föreställningar och antaganden kan utmanas, är ett värdefullt redskap för att skapa förutsättningar för förändringar som kan leda till verksamhetsutveckling (Handal 1999; Lycke \& Handal, 2012). Jag ser det kollaborativa arbetet som en meningsskapande aktivitet där också maktaspekter och sociala förhållanden som påverkar vårt sätt att tänka och handla kan synliggöras. Därmed kan det kollaborativa arbetet leda till en omformulering av de tankemönster vi använder för att förstå oss själva och världen.

\section{Undersökningens design och metod}

Undersökningen har genomförts i nära relation till arbetet i två forskningscirklar med inriktning mot att utveckla folkbibliotekens läsfrämjande arbete. En forskningscirkel är en metod och en mötesplats för kunskapsbildning och professionell utveckling och därigenom också ett redskap för förändring och utveckling av en verksamhet (Lindholm, 2008; Persson, 2009). Studieobjektet är deltagarnas egen praktik. Arbetssättet är nära besläktat med aktionsforskning, i synnerhet den interaktiva formen där demokratisk dialog i en kritisk och reflekterande gemenskap eftersträvas (Svensson, 2007; Fricke, 2013). I en forskningscirkel får deltagarna möjligheter att 
systematiskt reflektera över en specifik fråga eller ett problem i sin professionella verksamhet och att utforska denna verksamhet i dialog med andra deltagare. Processen kan delas in i tre faser, enligt figuren nedan, vilka har en tendens att överlappa varandra.

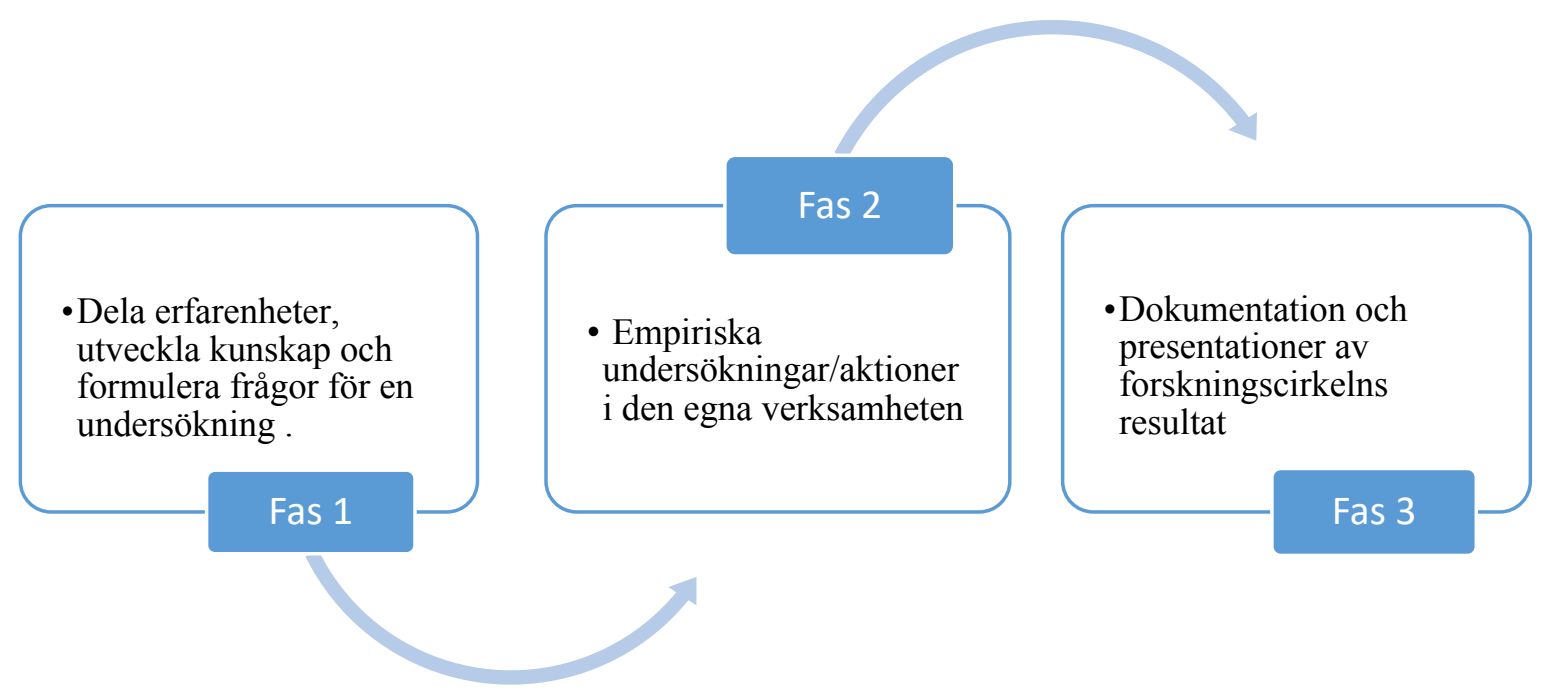

Figur 1. De tre faserna i en forskningscirkel

I den första fasen delar deltagarna kunskaper och erfarenheter, diskuterar problem och formulerar frågor. Designen av de empiriska undersökningarna sker gemensamt $i$ gruppen för att sedan genomföras och dokumenteras som individuella projekt i deltagarnas verksamheter. Den sista fasen ägnas åt diskussion av, reflektion över och presentation av projektens resultat. Att läsa och diskutera forskningslitteratur, använda teorier och begrepp för analys och reflektera över relationen mellan teori och praktik är viktiga delar i processen. Det ömsesidiga utbytet av erfarenheter, kunskaper och idéer tillsammans med resultatet av projekten blir en bas för utveckling av deltagarnas professionella verksamheter.

Min roll som handledare var att ge utrymme för deltagarna att på så lika villkor som möjligt ta del av varandras erfarenheter och kunskaper i ett öppet och tillitsfullt samtalsklimat. I ett sådant samtalsklimat ska det kännas tryggt att både ge och ta kritik och utmaningar från olika perspektiv ska ses som en tillgång (Bergman, 2014; 2016b). I syfte att fördjupa diskussionen om gruppens betydelse introducerade jag begreppet kritiska vänner (Handal, 1999). Begreppet är ett användbart tankeredskap (Lotman, 1990) i ett förändrings- och utvecklingsarbete där människor ska ta del av varandras arbete och sätt att tänka och handla, vilket ibland kan vara känsligt. Ett redskap för reflektion och självreflektion byggdes in i forskningscirkelns arbete genom arbetet med en reflekterande loggbok. Deltagarna uppmuntrades att ifrågasätta, se begränsningar och alternativa lösningar, istället för att reproducera kunskap. Det reflektiva skrivandet tillsammans med den kritiska läsningen av texter med potential att utmana samt de frågor som dök upp i anslutning till planering och genomförande av projekten, blev redskap för perspektivbyten och kritiska reflektioner i mötet med andras kunskaper, erfarenheter och sätt att tänka och agera. De reflekterande loggböckerna ingår, enligt överenskommelse med deltagarna, inte i underlaget för min undersökning men användes återkommande som stöd för gruppernas diskussioner och som stöd för planering och genomförande av deltagarnas projekt. Spår av det reflekterande skrivandet finns också i deltagarnas bidrag till antologin, där deltagarna uppmuntrades att dela med sig av de tankar och känslor som uppstod $\mathrm{i}$ arbetet med projekten.

I processen bidrog jag med teoretiska perspektiv, forskningslitteratur och redskap för analys. Min roll var också att ställa frågor som uppmuntrade till diskussion och kritisk reflektion. Att leda arbetet i cirkeln och stödja deltagarna i deras forskningsprojekt sattes i förgrunden under hela processen men deltagarna var samtidigt 
informanter i mitt forskningsprojekt. Den dubbla rollen som forskare och handledare har krävt kontinuerlig reflektion och självreflektion. Ett reflekterande förhållningssätt är ett viktigt inslag $i$ och en del av tolkningsarbetet $i$ etnografisk forskning och innebär att forskaren undersöker premisserna för sina aktiviteter och sin roll i forskningsprocessen (Alvesson \& Sköldberg, 2009). Som redskap för detta använde jag en reflekterande loggbok där jag i anslutning till möten, intervjuer och transkriberingen av inspelat materialet kontinuerligt reflekterade över mina egna val, min maktposition, mina iakttagelser och mitt sätt att tänka kring och förstå olika företeelser. Vidare reflekterade jag över hur jag genom min personliga och intellektuella närvaro och min interaktion med deltagarna påverkade dem och den sociala praktik jag undersökte (Cohen, Manion \& Morrison, 2007). Närhet till deltagarna och deras perspektiv var nödvändigt för att stödja samtalsklimatet i grupperna. Den reflekterande loggboken, teorier och begrepp användes för att skapa kritisk distans i analysprocessen.

Underlaget för studien består av audioinspelade träffar och sju kvalitativa semistrukturerade intervjuer (Alvesson, 2011; Kvale, 2009), vilka genomfördes i par, grupp eller enskilt i forskningscirkelns slutskede, samt de reflektioner jag skrev i anslutning till träffar, intervjuer och transkriberingsarbete. Huvudfokus i intervjuerna var att få inblick i deltagarnas upplevelse och värdering av forskningscirkelns arbete.

Forskningsprojektet genomfördes i enlighet med de etiska principer för humanistisk och samhällsvetenskaplig forskning som utarbetats av Vetenskapsrådet (http://codex.vr.se) och som deltagarna fick både skriftlig och muntlig information om. Samtliga deltagare gav sitt samtyckte till att inspelade möten och intervjuer skulle få ingå i underlaget för min studie. Citerade utsagor från träffar och intervjuer är inte kopplade till individuella deltagare. Istället anges enbart vilken träff och vilken grupp som avses, t.ex. Träff 2, gr 1. Vid flera utsagor i dialog används bokstäver istället för namn för att läsaren ska kunna följa replikskiften.

Materialet har transkriberats för att utgöra underlag för analys $i$ en process av upprepade läsningar. Syftet $i$ ett första analysskede var att finna mönster i materialet för att så småningom konstruera teman som kunde bidra till förståelsen av forskningscirkelns arbete och dess potentialer. Allteftersom jag fick en allt bättre förståelse för materialet som helhet kunde också separata delar förstås på ett annat sätt vilket i sin tur kastade nytt ljus över helheten. I denna hermeneutiska process har tolkningen av materialet utvecklats genom abduktion, en kontinuerlig växling mellan empiriska data och teori, där teorier använts för att få syn på och förstå olika innebörder i materialet (Alvesson \& Sköldberg, 2009).

\section{Resultat}

I resultatdelen analyserar jag de processer där deltagarna delar erfarenheter av det vardagliga arbetet och diskuterar frågor relaterade till arbetets villkor med stöd av varandra och forskningslitteratur. Störst utrymme ägnas åt den första fasen av processen där viktiga förutsättningar skapas för det fortsatta kollaborativa arbetet medan arbetet med de olika projekten får mindre utrymme. Det första avsnittet har fokus på de första träffarna där grunden läggs för gruppernas kollabortiva arbete genom utvecklandet av en reflekterande praktik. I de följande avsnitten fördjupas analysen av de resurser forskningscirkeln erbjuder genom interaktion och kritisk reflektion. Avsnitt tre bygger på intervjumaterialet och rör hur deltagarna ser på forskningscirkeln som resurs för kompetens- och verksamhetsutveckling. Avslutningsvis diskuteras studiens resultat.

\section{Formandet av en reflekterande praktik}

I den första fasen informerades deltagarna om forskningscirkeln som form för kompetensutveckling och vad som förväntades av dem som deltagare. Jag introducerade också loggboksskrivandet som metod för att samla tankar, känslor, reflektioner och idéer. Deltagarna fick möjlighet att berätta om sin egen verksamhet och de problem och möjligheter de upplevde i det läsfrämjande uppdraget. Behovet av att dela sådana erfarenheter med andra var framträdande.

Samtalsämnena i de första träffarna handlar i stor utsträckning om de stora förändringar som skett i yrket, hur komplext bibliotekariens arbete är men också om yttre faktorer som styr verksamheten. Graden av igenkänning 
i samtal och berättelser är hög när samtalet gäller frågor om bemötande, att ge boktips, brist på tid för läsning och prioriteringar som måste göras. Reflektionerna handlar i första hand om innehållet i arbetet och om hur arbetet genomförs, alltså vad och hur, men deltagarna lyfter också maktförhållanden som påverkar deras arbete. Ett exempel är den redovisning av verksamheten i kvantiteter som lokala politiker kräver och som ifrågasätts av bibliotekarierna:

\footnotetext{
"Ja alla dessa nyckeltal, vad ska man ha det till?" (Träff 2, gr 2).

"Det blir så mycket fokus på hur många besökare vi haft, hur många böcker vi lånat ut." (Träff 3, gr 1).

"Där sitter vi och klämmer in alla olika saker i kategorier men ett språkkafé som kulturellt integrerade verksamhet hur kan det mätas?" (Träff 3, gr 2).
}

Deltagarna är kritiska till att politiker har makten att styra deras arbete, inte minst genom krav på redovisning i kvantitativa mått, det som går lätt att mäta, och vill att politikernas uppmärksamhet istället ska riktas mot kvaliteterna i det arbete som bibliotekarierna gör. Också här stannar reflektionerna vid att beskriva ett problem. Ett återkommande samtalsämne rör hur biblioteken kan nå de svagaste läsarna. Ämnet dyker upp i Träff 2 i anslutning till samtal om Läsandets kultur (Sverige. Litteraturutredningen, 2012) som visar att Sveriges befolkning har relativt stabila läsvanor på en hög nivå men att det också finns "orosmoln". Det gäller läsfärdigheten hos unga och skillnader i läsvanor mellan olika socioekonomiska grupper. Den fråga som blir föremål för den kollaborativa reflektionen är hur bibliotekens läsfrämjande arbete ser ut i förhållande till de grupper som lyfts fram som de svagaste läsarna. Detta visar sig vara en viktig men också känslig fråga för deltagarna. Frågan återkommer i flera träffar och påverkar så småningom de flesta deltagares val av projekt. I samtalen betonas emellertid att det samtidigt är viktigt att fortsätta satsa på de trogna biblioteksbesökarna: "Man pratar ju ofta om hur vi ska nå dom som inte kommer men vi kan väl också göra något för dom som kommer, dom som redan är frälsta ska inte lämnas ensamma." (Träff 2, gr 1).

Ytterligare bränsle till diskussionen om prioriterade grupper får deltagarna i rapporten Läsandet bär demokratin. Om folkrörelsernas läsfrämjande erfarenheter och arbetsformer. (Arbetsgruppen för ett läslyft i Sverige, 2013). Rapporten upplevs som en av de mest inspirerande inte minst för att den betonar läsfärdighetens och läsvanornas betydelse i ett demokratiperspektiv. De problem som lyfts är inte nya för deltagarna men leder till kritiska reflektioner (Mezirow, 1991) över det läsfrämjande arbetets betydelse för att minska skillnader i läsvanor och läskunnighet. Rapporten ger ett historiskt perspektiv på folkrörelsernas läsfrämjande arbete som får deltagarna att uppmärksamma skillnaden mellan dem som uppifrån ville "bilda folket" och folkrörelsernas ståndpunkt att folkbildningen måste ske genom människorna själva (s. 21). I reflektionerna delar deltagarna känslor och tankar om att de själva tillhör den grupp som "kommer uppifrån", den grupp som ofta ser den skönlitterära läsningen som självklar. Här utmanas deltagarna genom att yrkesrollen och föreställningarna om självklarheten i den skönlitterära läsningens granskas och ifrågasätts. Reflektionerna blir kritiska. I intervjuerna nämns läsningen av och diskussionen om Läsandet bär demokratin som en ögonöppnare och något som förändrat synen på den läsfrämjande verksamheten som viktig och i grunden demokratisyftande och som kanske kräver att bibliotekarier rör sig ut ur sin bekvämlighetszon, dvs. ut ur biblioteket. Det kanske till och med kräver att bibliotekarien ibland tar ett steg tillbaka och överlåter det läsfrämjande arbetet till någon annan.

I de diskussioner som följer på läsningen av Läsandet bär demokratin (2012) väcks de svåraste frågorna, de som sätter bibliotekariens yrkesroll och biblioteket som demokratisk institution i gungning: Hur kan ett läsfrämjande arbete utformas som riktar sig till dem som inte läser eller läser lite? Är det bättre att lämna över resurser och ansvar till någon annan? Kan bibliotekarien och biblioteket fylla en viktig funktion i detta arbete och i så fall hur? Hur kan biblioteken samverka med föreningar, arbetsplatser, arbetsgivare, läsombud, barnmorskor, fackförbund, lärare etc.? Frågorna hämtar sin näring i ambivalenser, i förhållanden som oroar deltagarna eller som de är missnöjda med, så kallade disorienting dilemmas (Mezirow, 1998). I den kritiska reflektion som följer finns en potential för att vidga och kanske omformulera en tidigare förståelse av ett fenomen, en upplevelse eller av sig själv. 
Genom att ge stort utrymme för deltagarnas röster och möjlighet för både igenkänning och bekräftelse skapas viktiga förutsättningar för gruppens fortsatta arbete. I grupperna finns en beredskap för att låta sig utmanas av andras perspektiv. Erfarenhetsbaserade berättelser och den litteratur som läggs fram för diskussion medierar en social verklighet som deltagarna kan känna igen och blir viktiga resurser i den reflekterande praktiken. I intersubjektiviteten (Rommetveit, 1974) skapas en känsla av gemenskap där det arbete som deltagarna redan gör på de olika biblioteken kan bekräftas. Samtidigt bär samtalen spår av ifrågasättanden där föreställningar och förgivettaganden kan utmanas. För att skapa större förutsättningar för kritisk reflektion ger jag grupperna utrymme för reflektion över samtalens innehåll och form. Detta sker genom att vi tillsammans reflekterar över forskningscirkelns kollaborativa arbete med utgångspunkt i begreppet kritiska vänner (Handal, 1999). Vidare diskuteras den kritiska reflektionens betydelse, där invanda föreställningar och antaganden kan utmanas (Mezirow, 1998; Somekh, 2006; Mälkki, 2011), som resurs i det fortsatta arbetet.

\section{Kritisk reflektion och kunskapsutveckling i interaktion med kollegor}

De texter som läses till träffarna spelar en viktig roll i det kollaborativa arbetet. Texterna väljs från gång till gång för att ligga i linje med gruppernas behov och önskemål. Samtalen om Läsandet bär demokratin (2012) relateras till rapporten Synen på skönlitteratur för vuxna på svenska folkbibliotek (Ehrenberg m.fl., 2015) som lästes till den tredje träffen då Magnus Persson, en av medförfattarna, deltar i samtalen. Rapporten lyfter fram de passionerade läsarna och bibliotekens rika utbud av aktiviteter; bokfrukostar, högläsning med bok- och filmtips, maratonläsning av lokala kändisar, författarhelger, mingel med bokprat, tilltugg och dricka etc. (s. 7). Rapporten kommenteras i båda grupperna: "Det skulle vara intressant att få veta något om dom som inte kommer till biblioteket också" (gr 1), "De som pekas ut som icke-läsare, t.ex. vuxna män. Hur når man dom? Det kanske är den knepigaste frågan." (gr 2).

Läsningen av Ehrenberg m.fl., (2015) ger upphov till flera samtalsämnen präglade av igenkänning, kritisk reflektion och självreflektion i relation till de ambivalenser, självklarheter och till den optimism och tvärsäkerhet som de intervjuade bibliotekarierna ger uttryck för i Magnus Perssons artikel "Litteraturförmedlingens villkor på svenska folkbibliotek". Känslorna inför litteraturförmedlingen visar sig vara motstridiga: "Man vill förmedla men samtidigt kan jag ibland undra varför och vad vi vill med det." (gr 2). Persons undersökning lyfter fram en rad "ömma punkter" som visar sig vara lätta att känna igen sig i: "Detta med det självklara i att läsning är bra ..., ja man börjar fundera." (gr 1). "Varför man ska läsa? Som bibliotekarie hade jag gärna velat ha ett tydligt svar på den frågan" (gr 1).

De frågor som deltagarna ställer leder till kritik av förgivettaganden om den skönlitterära läsningens självklart goda effekter. I deltagarnas samtal uttrycks samma ambivalenser som i den lästa texten kring den breda lättillgängliga litteraturen som måste finnas för att nå alla, kontra den smala som många bibliotekarier fortfarande vill förmedla. "Det känns som om man gör fel hur man än gör. Vi tar fram den goda litteraturen och då är det fel och om vi bara ger folk vad dom vill ha då är det fel". (gr 1). Parallellt med ambivalensen finns också mer tvärsäkra ställningstaganden: "Det är lönlöst att försöka tvinga på folk nåt som är för avancerat eller smalt" (gr 1).

I grupp 2 tar diskussionen en något annan vändning då en av deltagarna framhåller att ambivalensen kring varför och vad är av godo: "Allt prat om den goda litteraturen och populärkulturen det är en diskussion som ska hållas levande eftersom det inte finns något rätt svar, det får lov att vara en ambivalens". Dialogen fortsätter i kritisk och självkritisk anda:

Men det handlar ju bara om det som vi tycker om, det som är gott [den goda litteraturen], men det som låntagarna tycker om eller det som assistenterna läser ... ja det är ömma punkter (A).

Ja, vad ska vi jobba med? (B)

Och hur? (A)

Vi köper in allt men gör ingen insats runt det vi köper. (B)

Överhuvudtaget att försöka lyfta den här diskussionen är ju känsligt. Alltså varför tycker vi detta är bra, varför köper vi detta? (A) 


\author{
/.../ \\ Jag trodde inte att det var så laddat nu. Det var ju mer när vi aldrig hade dom böcker som folk frågade efter, \\ det var ju tråkigt på nåt sätt. (C)
}

Deltagarna efterlyser en levande diskussion om bokval, om varför vissa böcker köps in och andra inte eller varför vissa böcker finns på undanskymd plats. Frågorna blir självkritiska och känsliga. I den fortsatta dialogen får olika synpunkter brytas mot varandra. Å ena sidan framställs bibliotekarier som en yrkesgrupp som inte är van vid att utsättas för kritik och som inte talar i klartext om vad de står för, t.ex. i frågor om bokval, vilket leder till att bibliotekariers arbete inte blir synliggjort, "alltså synen på bibliotekarier är ju fortfarande att det är dom som lånar ut böcker". Andra deltagare menar å andra sidan att det görs så mycket mer på biblioteken numera och att de får mycket respons från de som kommer på evenemangen.

\author{
Men dom som inte kommer ... dom får ju aldrig veta hur bra vi är eller om vi gör rätt saker. (C) \\ Ja, gör vi rätt grejer över huvud taget? (A) \\ Vi är beroende av den positiva feedbacken men tittar vi någonsin kritiskt på det vi gör? (B) \\ Det kan ju vara så att vi inte vet vad vi gör. (A)
}

I diskussionerna blir ambivalensen kring yrkesrollen, målgrupper och kriterier för bokval synliga, liksom behovet av att ha en öppen kritisk diskussion i dessa frågor. Att befinna sig i ett ambivalent tillstånd och tillsammans brottas med svårigheter kan vara frustrerande men också leda till att vi får syn på de förgivettaganden som styr hur vi tänker och handlar. Ambivalensen öppnar upp för nya insikter som kan bli drivkrafter för förändring (Engeström \& Sannino 2009:4, 7; Somekh, 2006).

Till träff 3 läser deltagarna också Magnus Perssons artikel "Att läsa Lolita på lärarutbildningen" (2010). I artikeln diskuteras textval i lärarutbildningen mot bakgrund av en klassrumsstudie där studenter läser Vladimir Nabokovs Lolita, en roman som medvetet valts för att provocera. Texten utmanar myten om "den goda litteraturen" och diskuterar litteraturundervisningens vad, hur och varför. Texten verkar provocerande också på deltagarna i grupperna och leder till erfarenhetsutbyte och reflektion. En av deltagarna menar att det finns en ängslighet inför bokval också i bibliotekets bokcirklar, "risken är att man väljer bort böcker som kan leda till känsliga diskussioner". Deltagarna har också erfarenheter av frågor om bokval från föräldrar och skola där det handlar om att försäkra sig om att böckerna "inte får innehålla något som kan göra att barnen far illa" (Träff 3, gr 1). Här ges exempel på böcker för olika åldersgrupper, som debatterats i medierna och sedan blivit en diskussion också på landets bibliotek t.ex. En liten Skär och många små brokiga (Wirsén 2006) och Kort kjol (Waldén 1998). I båda grupperna diskuteras lärares krav på att böcker ska vara tydliga, pedagogiska och nyttiga, "det får inte vara känsligt, inget barn får bli upprört (Träff 3, gr. 2). I denna fråga finns många synpunkter som alla pekar åt samma håll: "alla ungdomsböcker handlar ju om något slags problem", "det blir ju väldigt förljuget om alla berättelser för barn handlar om underbara familjer där alla har det bra". (Träff 3, gr 2).

I båda grupperna glider samtalet in på lärares förhållningssätt till böcker och läsning och bibliotekarierna förhåller sig öppet kritiska till lärarnas litteraturundervisning. De menar att kraven många gånger är motstridiga: "En sån bok [Kort kjol] borde man väl kunna jobba med pedagogiskt. Vad är det man vill ha? Man ska dels kunna diskutera men det får inte vara känsligt. Vad blir kvar?" (Träff 3, gr 1). I grupp 1 ifrågasätts instuderingsuppgifter till läsningen och skrivandet av recensioner som bibliotekarierna menar styr elevernas upplevelser. Samtidigt betonar deltagarna i båda grupperna att samarbetet med lärarna och skolan måste utvecklas, vilket också är en viktig slutsats som dras i Läsandets kultur (Sverige. Litteraturutredningen, 2012). "Vi behöver utveckla vårt samarbete med pedagogerna och inte bara ge tips om litteratur utan också diskutera pedagogik". Kritiken av lärares bokval och förhållningssätt till böcker och läsning stannar i ett beskrivande av upplevda problem men här finns också öppningar mot reflektion över processer när deltagarna diskuterar samarbete som en möjlig väg för att lösa problem. 


\section{Forskningscirkeln som resurs i arbetet med projekten}

I de följande träffarna fortsätter deltagarna att använda sig av sina erfarenheter, den litteratur vi läser till varje gång och de framväxande små-skaliga projekten i en fortsatt dialog om den läsfrämjande verksamheten, dess objekt och betydelse i ett samhällsperspektiv. I fas två och tre genomför och dokumenterar deltagarna sina projekt och behovet av stöd för skrivandet av texter till rapporten är stort. Det gemsamma arbetet med textrespons tar allt större utrymme vid träffarna, vilket gör att utrymmet för gemensam läsning minskar.

I de frågor som formuleras i träff 2 och 3 finns embryon till de projekt som senare kom att genomföras inom ramen för forskningscirkeln. I slutet av träff 3 presenterar deltagarna sina första idéer och flera projekt riktar sig till de prioriterade grupper som lyfts fram i Läsandets kultur (2012). Det gäller till exempel ungdomars läsning, bokcirkel om science fiction och fantasy i syfte att locka fler män och unga till biblioteket, läsning för nyanlända på biblioteket och inom ramen för SFI-undervisning. Andra projekt kom att handla om bemötande och spontana boksamtal, hur biblioteket kan agera läsfrämjande i rummet och om läsfrämjande för vuxna och barn tillsammans. Slutligen finns ett projekt där den deltagande bibliotekschefen skapar en egen forskningscirkel för sin personal i syfte att söka nya möjligheter i det läsfrämjande arbetet.

I båda grupperna finnas en enighet om att bibliotekariers arbete behöver bli mer utåtriktat, mot skolor, bostadsområden och arbetsplatser, men också om att det vardagliga arbetet och mötet med dem som av olika skäl söker sig eller hänvisas till biblioteket behöver uppmärksammas och utvecklas. På folkbiblioteken liksom i skolan påverkas verksamheten på ett påtagligt sätt av samhälleliga förändringar, förändringar som ibland sker snabbt och är omfattande. Ett exempel är de senaste årens flyktingströmmar som lett till ett intensivt arbete med språkcaféer och andra aktiviteter för nyanlända på många bibliotek. På biblioteken skapas en mötesplats och ett sammanhang där nyanlända kan ta sina första steg mot ett nytt språk och en ny gemenskap. Situationen kräver flexibilitet, kreativitet, samverkan och handlingsberedskap för förändring hos bibliotekens personal. Två av projekten kom handla om läsfrämjande arbete för nyanlända vuxna.

Att tvingas tänka om i arbetet med projekten är mer regel än undantag, vilket leder till att deltagarna med stöd av gruppen prövar sig fram från aktion till aktion. Projekten utvecklas i möten mellan olika röster som bryts mot varandra (Bakhtin, 1984; Wertsch, 1998) och i växelverkan mellan individuellt och kollaborativt arbete. Det kollaborativa arbetet (Bruce, Flynn \& Stagg Peterson, 2011; Capobianco, 2007) innebär att deltagarna aktivt interagerar för att dra nytta av varandras kunskaper och erfarenheter. Detta visar sig i deltagarnas beredskap att agera som kritiska vänner (Handal, 2009) genom att lyfta fram andra perspektiv, uppmuntra, ge råd och kritiskt granska varandras texter. På så sätt växer projekten fram med forskningscirkeln som resurs.

\section{Deltagarnas röster om processen och dess potentialer för förändring och utveckling}

I intervjuerna ställer jag öppna frågor om deltagarnas upplevelser av forskningscirkelns arbete. Alla deltagare lyfter fram det kollegiala erfarenhetsutbytet och stödet i form av samtal och reflektion: "Man tänker ju hela tiden men det finns inget sammanhang att reflektera i eller fördjupa diskussionen i, här får man både verktygen och tiden”. Genom samtalen har de blivit delaktiga i varandras processer, inspirerat varandra och fått idéer de själva vill testa. Den gemensamma reflektionen över de texter som lästes till träffarna är en av flera delar som lyfts fram som givande och som något de annars inte har tid med. "Jag har fått insikter och varenda sak jag läser kan jag applicera på det jag gör och det är jättehäftigt, det hade jag inte gjort annars." De praktiknära texterna upplevdes som relevanta eftersom de var lätta att känna igen sig i samtidigt som de var forskningsbaserade. Deltagarna uttrycker att de hade velat ha mer tid för textsamtal.

\footnotetext{
Varje tillfälle har gett oerhört mycket, det har varit en resa, men jag hade velat ha mer tid för att diskutera. Just det här att man har diskuterat mer än vad man gör till vardags. Vi har ju reflekterat kring allting och det har gjort att man faktiskt förändrats.
}

Enligt deltagarna har gruppen och det öppna klimatet betytt mycket också i planering och genomförande av projekten. "Vi fick stöd i att våga gå utanför ramarna, till andra grupper som är en större utmaning". Gruppen 
har inspirerat och ställt frågor som lett arbetet med projekten framåt: "Hade vi inte haft den här gruppdiskussionen så hade vårt upplägg sett annorlunda ut". Projektdelen ses också som en viktig del $\mathrm{i}$ arbetet.

Aktionerna är jätteviktiga, det var ju där själva utmaningen låg, i alla fall för mig, att utmana sig själv, att hitta nya arbetsformer och att testa något nytt. Det går att komma till en insikt utifrån texter och diskussioner men för min del hade det varit omöjligt att utvecklas så mycket utan aktionerna.

Emellertid upplever några att projektdelen fått ta för mycket tid, i synnerhet i slutet då texterna till rapporten skulle skrivas. I en av gruppintervjuerna uttrycker deltagarna att tiden varit för knapp och att de hellre prioriterat samtalen utifrån lästa texter och teori, trots att projekten var givande. Gruppen uttrycker frustration över att inte hinna med och kunna göra någon av delarna så bra som de önskat. Projekten "ger en möjlighet att utforska något specifik och iaktta effekten av det man gör /.../ men då ska det finnas tid att förankra det och genomföra det ordentligt". För den här gruppen, liksom för några andra deltagare, fanns inget stöd från arbetsplatsen i form av tid för att delta i forskningscirkeln, vilket naturligtvis gör skillnad i synnerhet då tiden för forskningscirkeln som helhet komprimerats från tre till två terminer. Flera deltagare framför kritik mot att de två presentationerna, en muntlig under en heldag och det skriftliga bidraget till antologin, tagit mycket tid i anspråk, vilket lett till att utrymmet för reflektion minskat i slutskedet. Att arbetsbördan varit tung bekräftas i flera intervjuer och ett par deltagare upplever också att skrivandet mot slutet blivit alltför prestationsfyllt. Samtidigt finns det en stolthet inför publiceringen, "att det blir en antologi gör nånting med ens självbild".

En av de frågor jag ställer gäller om synen på läsfrämjande förändrats genom arbetet i forskningscirkeln. Några av svaren är att begreppet har vidgats: "det kan vara så mycket" och att man inser "vidden och vikten av det". En av deltagarna menar att hon genom de texter vi läst fått upp ögonen för innebörden $i$ att biblioteken i grunden är en demokratisyftande verksamhet, "inte bara förströelse utan mycket mer". För andra har det inte skett några förändringar i synen på vad läsfrämjande är men cirkeln ha lett till fler kritiska reflektioner över det läsfrämjande arbetet. "Jag har inte förändrat min bild av vad läsfrämjande är men jag tycker det är viktigt att det blir en levande diskussion på alla bibliotek" säger en av deltagarna i en parintervju. Tillsammans ger de exempel på frågor som inte är så lätta att besvara men som behöver ställas: Varför ska människor läsa mer egentligen?, Varför har vi ett bibliotek? Varför ska vi bokbubbla på onsdagar och vad vill vi med det?

För att skapa förutsättningar för förändring och utveckling i ett mer långsiktigt perspektiv ska en forskningscirkel idealt ge deltagarna tillgång till en demokratisk dialog i en kritisk reflekterande gemenskap där teori och praktik kan befrukta varandra, vilket kräver tid och kontinuitet (Se t.ex. Persson 2007; Svensson 2007, Fricke 2013). Om resultatet blir mer bestående återstår att se men deltagarnas utsagor vittnar om att de tror att det kommer att bli så. De lyfter bland annat fram att regelbundenheten och kombinationen av teori och praktik gjorde att det som diskuterades "blev mer förankrat inom mig". Samma deltagare berättar hur hon och kollegorna gärna kastar sig in i saker väldigt snabbt och "bara gör och gör utan att tänka först" men att hon nu vågar stanna upp, ifrågasätta mer. Hon hoppas att det ska stanna kvar och att de ska kunna bygga vidare. I en annan grupp poängteras aktionernas betydelse: "Mycket kan hända i en cirkel där man bara läser och diskuterar men ska det ge något bestående behöver man omsätta idéer i praktiken."

\section{Diskussion}

Om arbetet i en forskningscirkel ska upplevas som värdefullt behöver initiativen komma från deltagarna själva och arbetet utgå från problem som de upplever i sin vardag. I forskningscirkeln arbete användes deltagarnas kunskaper och erfarenheter som resurser, vilket gav dem en nyckelroll i processen, vilket enligt Somekh (2006) är en viktig förutsättning för varaktig förändring och utveckling av en verksamhet. Att deltagarna kom till forskningscirkeln med en vilja till förändring, som grundade sig i upplevda dilemman (Mezirow) i den läsfrämjande verksamheten, gjorde att de hade en beredskap för att låta sig utmanas av nya perspektiv och tillsammans försöka lösa gemensamma problem. Denna beredskap gav också goda förutsättningar för den kritiska reflektionen. 
Det kollaborativa arbetet värderas högt av deltagarna och anses av flera vara mer värdefullt än genomförandet av aktionerna då det gav tillgång till en mångfald av röster från kollegor och från den litteratur som lästes. Dialogen och den reflekterande praktik som formades var rik på idéer och perspektiv som kunde blir redskap för kollaborativa reflektioner och stöd för utveckling av ny kunskap och förståelse. Reflektionerna rörde ofta innehållet i bibliotekariers arbete; strategier för att lösa problem, förhållningssätt till arbetsuppgifter och hur prioriteringar kan göras. Dessa reflektioner handlar om det som är men har också ifrågasättande inslag som t.ex. i diskussioner om politikerstyrningen av bibliotekens verksamhet eller lärares snäva syn på vilka böcker som är lämpliga för deras elever. Dessa reflektioner blev aldrig kritiska i den meningen att de ledde till att problemet omdefinierades eller att det skedde en grundläggande förändring i deltagarnas antaganden eller agerande, så som det kan bli synligt i mitt material. Jag menar att de ändå hade stor betydelse i gruppernas interaktion genom att de synliggjorde gemensamma problem som kunde belysas utifrån flera olika perspektiv. Interaktionen kring dessa frågor gav möjlighet till erfarenhetsutbyte, igenkänning och bekräftelse, vilket fungerade stärkande för känslan av delaktighet och samhörighet i grupperna, samtidigt som den gav tillgång till en spänning mellan olika röster (Bakhtin, 1984) som jag menar kan leda till en fördjupad förståelse och nya kunskaper.

I det analyserade materialet finns emellertid flera sekvenser där reflektionen, enligt Mezirows definition, blir kritisk och därmed bär på en potential att förändra antaganden och sätt att tänka och handla. Det sker t.ex. när deltagarna i anslutning till läsningen av Läsandet bär demokratin (2012) reflekterar över innebörden i bibliotekens demokratisyftande arbete, "vidden och vikten" av det, vilket leder till att de i sina projekt utforskar nya former för att mer medvetet rikta verksamheten mot grupper vars intresse för läsning är lågt, grupper som inte besöker biblioteket eller grupper som har ett särskilt behov av att få tillgång till läsning, språk och gemenskap. Den kritiska reflektionen blir också uttalad i kritiken av förgivettaganden om det självklart goda i den skönlitterära läsningen och ambivalensen kring bibliotekens utbud och strävan att ge alla vad de vill ha eller att våga stå för ett snävare utbud.

I min roll som handledare var närheten till deltagarna avgörande för att möjliggöra ett öppet och tillitsfullt samtalsklimat. Enligt Svensson (2007) krävs närheten för att kunna stödja förändring och utveckling, samtidigt som handledaren måste kunna utmana och provocera för att leda arbetet framåt. Jag menar, i linje med Svensson (a.a.), att det inte behöver finnas någon konflikt mellan närhet och distans i detta avseende. Istället skapade närheten förutsättningar för att deltagarna, när så krävdes, dels skulle acceptera att jag ibland provocerade dem, dels själva våga tillämpa ett mer distanserat kritiskt förhållningssätt.

I utbytet av kunskaper och erfarenheter och i dialog om texter och projekt utgjorde deltagarna viktiga resurser för varandra. Deltagarna kom att se på ambivalenser och konflikter på ett mer nyanserat sätt, som något som kan hålla liv i en nödvändig debatt och som kan få vara stående inslag i det vardagliga arbetet. Det provocerande och störande kan utgöra viktiga drivkrafter för förändring av vårt sätt att tänka och därmed också drivkrafter för verksamhetsutveckling (Mezirow 1998; Engeström \& Sannino 2010).

Relationen mellan reflektion och handling är komplicerad och förändringar i sätt att tänka leder inte alltid till förändringar i det praktiska arbetet (Taylor 2007; Mälkki \& Lindholm-Ylänne, 2012). Ett förändringsarbete kräver handlingar i form av ett prövande av nya sätt att arbeta som i sin tur kan bli föremål för analys och fortsatt reflektion. Deltagarnas småskaliga projekt blev ett viktigt led i processen och upplevdes så av samtliga deltagare även om tiden var knapp. I projekten prövades deltagarnas flexibilitet och förmåga att tänka om, likväl som förmågan att stå ut med osäkerheten i att det inte finns några självklara svar eller i att hela tiden hålla öppet för förändring genom att låta den ena aktionen ligga till grund för planeringen av nästa, istället för att ha allt planerat från början till slut. Arbetet med de småskaliga projekten är en viktig del i forskningscirkelns arbete men bland deltagarna fanns också röster som hellre hade använt tiden till mer läsning, teori och kollektiv reflektion.

För att skapa förutsättningar för förändring och utveckling i ett mer långsiktigt perspektiv ska en forskningscirkel idealt ge deltagarna tillgång till en demokratisk dialog i en kritisk reflekterande gemenskap där teori och praktik kan befrukta varandra (se t.ex. Persson, 2007; Svensson, 2007, Fricke, 2013). Detta är förutsättningar som 
deltagarna menar att de fått tillgång till i forskningscirkelns arbete. De framhåller också att det skett förändringar i deras sätt att tänka om och förstå det läsfrämjande arbetet och att de tror att arbetet kommer att ge bestående resultat. Forskningscirkelns arbete relaterades konsekvent till en övergripande diskussion om bibliotekariernas förändrade yrkesroll och den utmaning som ligger $i$ att yrket kopplas till ett vidare samhälls- och demokratiperspektiv, där frågor om tillgång till språk, kunskap, makt och demokratiskt inflytande blir avgörande för hur verksamheten ska utvecklas. Resultatet av studien visar att deltagarnas arbete i forskningscirkeln, med det starka deltagarperspektivet och den reflekterande praktik som utvecklades, kan vara en viktig resurs i en sådan förändring- och utvecklingsprocess.

\section{Tack}

Slutligen vill jag rikta ett tack till Region Skåne vars ekonomiska stöd gjort det möjligt för mig att färdigställa denna artikel.

\section{Referenser}

Aagaard Nielsen, Kurt \& Svensson, Lennart (Red.) (2006). Action and Interactive Research: Beyond Practice and Theory. Maastricht: Shaker Publishing.

Alvesson, Mats \& Sköldberg, Kaj (2009). Reflexive Methodology: New Vistas for Qualitative Research (2nd ed.). London: SAGE Publications.

Alvesson, Mats (2011). Interpreting Interviews. London: SAGE Publications.

Arbetsgruppen för ett läslyft i Sverige (2013). Läsandet bär demokratin. Om folkrörelsernas läsfrämjande erfarenheter och arbetsformer.

Argyris, Cris (1993). Knowledge for Action: A Guide to Overcoming Barriers to Organizational Change. San Francisco: Jossey-Bass.

Audunson, Ragnar (2005). The public library as a meeting-place in a multicultural and digital context. The necessity of low-intensive meeting-places. Journal of Documentation, 61 (3), 429-441.

Bakhtin, Michail Michajlovic (1984). Problems of Dostoevsky's Poetics. Translated and edited by C.Emerson. Minneapolis: University of Minnesota Press.

Bergman, Lotta (2014). The Research Circle as a Resource in Challenging Academics' Perceptions of How to Support Students' Literacy Development in Higher Education. Canadian Journal of Action Research, 15(2), 3-20.

Bergman, Lotta (Red.) (2016a). Aktionsforskande bibliotekarier. En rapport om läsfrämjande verksamhet. Malmö: Region Skåne. https://utveckling.skane.se/siteassets/publikationer dokument/forskningscirklar Ir.pdf

Bergman, Lotta (2016b) Supporting Academic Literacies. University Teachers in Collaboration for Change. Teaching in Higher Education. 21(5), 516-531.

Bruce, Catherine, Flynn, Tara \& Stagg-Peterson, Shelley (2011). Examining what we mean by collaboration in collaborative action research: A cross case analysis. Educational Action Research, 19(4), 433-452.

doi:10.1080/09650792.2011.625667.

Capobianco, Brenda M. (2007). Science teachers' attempts at integrating feminist pedagogy through collaborative action research. Journal of Research in Science Teaching, 44 (1), 1-32. doi:10.1002/tea.20120. 


\section{NTik \\ Nordisk Tidsskrift for Informationsvidenskab og Kulturformidling}

Cohen, Louis, Manion, Lawrence \& Morrison, Keith (2007). Research methods in education (6th ed.). London: Routledge.

Ehrenberg, Maria m.fl. (2015). Synen på skönlitteratur för vuxna på svenska folkbibliotek: en rapport. Halmstad: Region Halland.

Engeström Yrjö, Sannino Annalisa (2010). Studies of expansive learning. Foundations, findings and future challenges. Educational Research Review, 5(1), 1-24.

Frenander, Anders \& Lindberg, Jenny (Red.) (2012). Styra eller stödja?: svensk folkbibliotekspolitik under hundra år. Borås: Institutionen Biblioteks- och informationsvetenskap/Bibliotekshögskolan, Högskolan i Borås.

Fricke, Werner (2013). A realistic view of the participatory utopia. Reflections on participation. International Journal of Action Research, 9(12), 168-191.

Handal, Gunnar (1999). Kritiske venner: Bruk av interkollegial kritik innen universiteten. Nylng. Rapport nr. 9. Linköping: Linköping University.

Hansson, Joacim (2015). Documentality and legitimacy in future libraries. An analytical framework for initiated speculation. New Library World, 116(1/2), 4-14.

Höglund, Lars (2012). Svenskarna och folkbiblioteken på 2000-talet. I Frenander, Anders \& Lindberg, Jenny (Red.), Styra eller stödja?: svensk folkbibliotekspolitik under hundra år, (pp. 271-291). Borås: Institutionen Biblioteks- och informationsvetenskap/Bibliotekshögskolan, Högskolan i Borås.

Kann-Christensen, Nanna \& Andersen, Jack (2009). Developing the library. Between efficiency, accountability and forms of recognition. Journal of Documentation, 65(2), 208-222.

Kvale, Steinar (2009). Interviews. Learning the Craft of Qualitative Research Interviewing. Los Angeles: SAGE Publications.

Kungliga biblioteket (2015). Bortom förlägenheten: bibliotekariens pedagogiska roll i utveckling. Stockholm: Kungl. biblioteket.

Langer, Judith (2005). Litterära föreställningsvärldar. Litteraturundervisning och litterär förståelse. Göteborg: Daidalos.

Lindholm, Yvonne (2008). Mötesplats skolutveckling: Om hur samverkan med forskare kan bidra till att utveckla pedagogers kompetens att bedriva utvecklingsarbete Stockholm: Stockholm University.

Lycke, Hofgaard, Kirsten \& Handal Gunnar (2012). Refleksjon over egen undervisningspraksis - et ledd i kvalitetsutvikling? I T. L. Hoel, B. Hanssen, D Husebø (Red.). Utdanningskvalitet og undervisningskvalitet under press? Spenninger i høgere utdanning, (pp. 157-183). Trondheim: Tapir Akademisk Forlag.

Lotman, Jurij M. (1990). Universe of the mind. A semiotic theory of culture. Bloomington: Indiana University Press.

Läsa för livet: regeringens proposition 2013/14:3. (2013). Stockholm: Riksdagens tryckeriexpedition [distributör].

Tillgänglig på Internet: http://www.regeringen.se/sb/d/16860/a/224959 
Mezirow, Jack (1991). Transformative Dimensions of Adult Learning. San Francisco: Jossey-Bass.

Mezirow, Jack (1998). On critical reflection. Adult Education Quarterly, 48(3), 185-198.

doi:10.1177/074171369804800305

Mezirow, Jack, and Associates (2000). Learning as Transformation: Critical Perspectives on a Theory in Progress. San Francisco: Jossey-Bass.

Michnik, Katarina (2014) What threatens public libraries? The viewpoints of library directors in Sweden. New Library World, 115(9/10), 426-437.

Mälkki, Kaisu (2011). Theorizing the Nature of Reflection. Helsinki: University Print.

Mälkki, K. \& Lindholm-Ylänne S. (2012). From reflection to action? Barriers and bridges between higher education teachers' thoughts and actions. Studies in Higher Education, 37(1), 33-50.

Nabokov, Vladimir Vladimirovič (2007). Lolita. Stockholm: Albert Bonniers Förlag.

Ny bibliotekslag. (2012). Stockholm: Kulturdepartementet, RegeringskanslietTillgänglig på Internet: http://www.regeringen.se/rattsdokument/departementsserien-och promemorior/2012/05/ds-201213/.

Persson, Magnus (2010). Att läsa Lolita på lärarutbildningen. Tidskrift för litteraturvetenskap, 40(3-4), 5-15.

Persson, Magnus (2015) Litteraturförmedlingens villkor på svenska folkbibliotek. I Synen på skönlitteratur för vuxna på svenska folkbibliotek. Region Halland/Kultur Halland.

Persson, Sven 2009. Research circles - a guide. Malmö: Centre for Diversity in Education, Malmö.

Ranemo, Cecilia (2017). Bibliotek 2016 : Offentligt finansierade bibliotek [Elektroniskresurs]. Kungl. Biblioteket. http://biblioteksstatistik.blogg.kb.se/files/2017/05/Rapport Bibliotek2016.pdf

Rommetveit, Ragnar (1974). On Message Structure: A Framework for the Study of Language and Communication. London: Wiley.

Somekh, Bridget (2006). Action Research: A Methodology for Change and Development. New York: Open University Press.

Statens kulturråd, (2014). Handlingsprogram för läsfrämjande. http://www.kulturradet.se/sv/Lasframjande/.

Svensson, Lotta (2007). Its being close that makes it possible to accept criticism! International Journal of Action Research, 3(3), 278-296.

Sverige. Litteraturutredningen (2012). Läsandets kultur: slutbetänkande. Stockholm: Fritze Tillgänglig på Internet: http://www.regeringen.se/rattsdokument/statens-offentliga-utredningar/2012/09/sou-201265/

Taylor, Edward W. 2007. An Update of Transformative Learning Theory: A Critical Review of the Empirical Research (1999-2005). International Journal of Lifelong Education 26(2), 173-191.

doi:10.1080/02601370701219475.

Wahldén, Christina (1998). Kort kjol. Stockholm: Tiden

Vetenskapsrådet. (2018, januari, 18). CODEX - regler och riktlinjer för forskning. http://codex.vr.se/. 
Wolf, Lars (1997). Till dig en blå tussilago: att läsa och skriva lyrik i skolan. Lund: Studentlitteratur

Vygotsky, Lev S. (1978). Mind in Society: The Development of Higher Psychological Processes. Cambridge: Harvard University Press.

Wertsch, James (1991). Voices of the Mind: A Sociocultural Approach to Mediated Action. Cambridge: Harvard University Press.

Wertsch, James (1998). Mind as Action. New York, Oxford: Oxford University Press.

Wirsén, Carin (2006). En liten skär och många små brokiga. Stockholm: Bonnier Carlsen.

' De projekt som genomfördes i forskningscirkeln är forskningsliknande då de har kvaliteter som återfinns i forskning. Vetenskaplig forskning är emellertid oftast mer omfattande, mer systematiskt genomförd och granskad i förhållande till vetenskapliga kriterier (se t.ex. Persson, 2009). 